\title{
Rumen metabolism and duodenal nutrient flow as affected by ration composition and antimicrobials in sheep
}

\author{
H Fébel, I Zsolnai Harczi, S Huszar \\ Research Institute of Animal Breeding and Nutrition, Dept of Physiology, 2053 Herceghalom, Hungary
}

The effects of two additives (salinomycin and avoparcin) in different concentrate to forage ratio diets on ruminal fermentation, nutrient digestion and duodenal flow were examined in this $2 \times 3$ factorial design experiment using six rumen and duodenal cannulated wether sheep. Diets were high concentrate to forage ratio 70:30 (C), C plus salinomycin (C + SAL), C plus avoparcin $(C+A V O)$, low concentrate to forage ration 30:70 (F), $F$ plus salinomycin $(F+$ $S A L), F$ plus avoparcin $(F+A V O)$. Additives were provided at $0.75 \mathrm{mg} / \mathrm{kg}$ BW. Sheep were fed diets at a rate of $60 \mathrm{~g} \mathrm{DM} / \mathrm{kg} \mathrm{BW} 0.75$ for 13 $\mathrm{d}$ adaptation followed by a $5 \mathrm{~d}$ collection period. During each collection period 12 duodenal samples were collected on days 1416. Rumen samples were taken on day 17-18 at 3 hour post feeding. $\mathrm{Cr}$-mordanted fibre and PEG were used as digesta passage markers and purine was used as microbial marker.

Neither salinomycin nor avoparcin affected $\mathrm{pH}$ value. The concentration of total VFA was lower in sheep fed C + SAL and C + AVO. Salinomycin and avoparcin increased molar proportions of propionate and iso-butyrate regardless of diet composition. Ruminal ammonia concentration was lower in sheep receiving $C+S A L, C+A V O$ and $F+S A L$ diets. The duodenal flow of $D M$ and $O M$ and apparent ruminal digestibility of DM were not affected by the antimicrobials. True ruminal digestion of $O M$ was significantly lower in sheep fed diet C + AVO while OM digested apparently increased by $F+A V O$. No differences in ruminal digestion of NDF, ADF, cellulose and hemicellulose were found in diets supplemented with salinomycin. The quantity of cellulose and hemicellulose digested in the rumen was increased by $F+$ AVO diet. Duodenal flow of total $N$, total AA, essential AA was unaffected by additives. Both non ammonia $N$ passage and non essential $A A$ flow were lower for $F+S A L$ than $F$. Salinomycin supplementation regardless of concentrate to forage ratio produced lower microbial $\mathrm{N}$ and higher dietary $\mathrm{N}$ flow to the duodenum and this change was associated with a lower value of true $\mathrm{N}$ digestion in the stomach. Avoparvin also decreased microbial $\mathrm{N}$ flow for both $\mathrm{C}$ and $\mathrm{F}$ diets but a larger proportion of dietary $\mathrm{N}$ passed to the duodenum and lower true $\mathrm{N}$ digestion were observed only in sheep receiving $\mathrm{C}+\mathrm{AVO}$. The supply of salinomycin and avoparcin lowered the efficiency of microbial protein synthesis regardless of diet composition.

It can be concluded that salinomycin and avoparcin had significant effect on both ruminal fermentation and nutrient digestion. Results of trials indicate no consistent relationship between diet composition and response of sheep to supplemental additives.

\begin{tabular}{|c|c|c|c|c|c|c|}
\hline & $\mathrm{C}$ & $C+S A L$ & $\mathrm{C}+\mathrm{AVO}$ & $\mathrm{F}$ & $F+S A L$ & $\mathrm{~F}+\mathrm{AVO}$ \\
\hline \multicolumn{7}{|c|}{ Duodenal flow (g/day) } \\
\hline Total N & 22.2 & 21.4 & 20.9 & 31.8 & 29.6 & 29.8 \\
\hline NAN & 20.7 & 19.9 & 19.5 & 30.6 & $28.8^{*}$ & 28.7 \\
\hline Microbial N & 17.9 & $14.8^{*}$ & $12.4^{*}$ & 16.6 & $12.4^{\star}$ & $14.4^{*}$ \\
\hline Dietary N & 2.7 & $5.1^{*}$ & $7.1^{\star}$ & 14.0 & $16.3^{*}$ & 14.3 \\
\hline \multicolumn{7}{|c|}{ Apparent digestion in the rumen (\% of intake) } \\
\hline DM & 53.7 & 53.2 & 54.0 & 44.2 & 45.0 & 47.8 \\
\hline OM & 62.7 & 62.1 & 62.6 & 52.9 & 53.8 & $56.4^{\star}$ \\
\hline $\mathrm{N}$ & 42.7 & 44.4 & 42.6 & 15.3 & $18.7^{*}$ & $22.2^{\star}$ \\
\hline \multicolumn{7}{|c|}{ Microbial synthesis ( $\mathrm{g} \mathrm{N} / \mathrm{kg}$ OM truly digested in rumen) } \\
\hline & 19.6 & $16.4^{\star}$ & $14.1^{*}$ & 20.2 & $16.8^{*}$ & $17.0^{*}$ \\
\hline
\end{tabular}

* $\mathrm{P}<0.05$ 